\title{
Surface Integrity at Reaming Operation by MT3 Head
}

Karel Kouril ${ }^{1}$, Robert Cep ${ }^{2}$, Adam Janasek ${ }^{2}$, Antonin $\mathrm{Kriz}^{3}$, Dana Stancekova ${ }^{4}$

${ }^{1}$ HAM-FINAL s.r.o., Vlárská 22, 62700 Brno, Czech Republic. kouril@ham-final.cz

${ }^{2}$ VŠB - Technical University of Ostrava, Faculty of Mechanical Engineering, Department of Machining and Assembly, 17. listopadu 15/2172, 70833 Ostrava - Poruba, Czech Republic. robert.cep@vsb.cz

${ }^{3}$ University of West Bohemia, Faculty of Mechanical Engineering, Department of Materials and Engineering Metallurgy, Univerzitní 22, 30614 Plzeň, Czech Republic. kriz@kmm.zcu.cz

${ }^{4}$ Zilina University on Zilina, Faculty of Mechanical Engineering, Departmenaof Machining and Manufacturing Techno ogies, Univerzitná 1, 01026 Zilina, Slovakia.dana.stancekova@fstroj.uniza.sk

Surface integrity reflects the properties of a material after it has been subject to some type of manufacturing process or modification during machining process and surface integrity can also have a great impact on a parts function. The changes limit the component quality or in the same cases performed the surface as an unacceptable. It has long been known that the method of surface finishing and combination of surface roughness, residual stress, cold work, or phase transformations strongly influence the service performance of manufactured parts as fatigue or corrosion. The main aim of the article is testing a high-productive reaming tool type MT3 with respect to different values of tool-life because holes making among the most important operation in machining and one of the most common in drilling operation.

Keywords: Machining, Surface Integrity, Reaming, Testing

\section{References}

[1] HAVLÍK, L. Integrita povrchu při vystružováni s využitím vystružovaci hlavice MT3. Brno 2012. Diploma thesis. Vysoké učení technické v Brně, Fakulta strojního inženýrství, Ústav strojírenské technologie. p. 88. Annexes 3. Head: Ing. Karel Kouřil, Ph.D.

[2] BUMBÁLEK, B. Integrita povrchu a její význam pro posouzení vhodnosti dané plochy pro její funkci. [online]. [vid. 2011-10-21]. VUT v Brně. Fakulta strojního inženýrství. Available from: http://gps.fme.vutbr.cz/STAH_INFO/2512_Bumbalek.pdf

[3] GRIFFITHS, B. Manufacturing Surface Technology: Surface Integrity and Functional Performance. 1st Edition. London: Penton Press, 2001. ISBN 1-8571-8029-1.

[4] COTELL C. M., SPRAGUE, J. A., SMIDT, F. A. ASM Handbook-Volume 5: Surface Engineering. ASM International, 1994. ISBN 978-0871703842.

[5] MÁDL, J. Integrita povrchu po obrábění. [online]. [vid. 2011-10-03]. Available from: http://web.tuke.sk/fvtpo/journal/pdf08/2-str-05-07.pdf

[6] NOVÁK, Z. Prostorová charakteristika textury povrchu. In: MM Průmyslové spektrum [online]. 7. 10. 2009, [vid. 2012-02-19]. Available from: http://www.mmspektrum.com/clanek/prostorova-charakteristika-textury-povrchu.html

[7] SVOBODA, E. Přednosti prostorového hodnocení textury povrchu v praxi. In: MM Průmyslové spektrum [online]. 7. 10. 2009, [vid. 2012-02-19]. Available from: http://www.mmspektrum.com/clanek/prednosti-prostorovehohodnoceni-textury-povrchu-v-praxi.html

[8] NOVOVIC, D., DEWES, R. C., ASPINWALL, D. K., VOICE, W. and BOWEN, P. The effect of machined topography and integrity on fatigue life. In: International Journal of Machine Tools \& Manufacture 44. 2004.

[9] KOUŘIL, K., VANĚK, V. Dokončovací operace vystružování. In: MM Průmyslové spektrum [online]. 14. 6. 2006, [vid. 2012-01-25]. Available from: http://www.mmspektrum.com/clanek/dokoncovaci-operace-vystruzovani.html

[10] FIALA, S., KOUŘIL, K. Moderní nástroje pro vystružování. In: Moderní výrobni technologie pro 21. století. Brno: Akademické nakladatelství CERM, 2009. ISBN: 978-80-214-3914- 6.

[11] FIALA, S., KOUŘIL, K.. Moderní nástroje pro dokončování děr. In: MM Prưmyslové spektrum [online]. 25. 4. 2007, [vid. 2012-02-16]. Available from: http://www.mmspektrum.com/clanek/moderni-nastroje-pro-dokoncovani-der.html

[12] LUČANÍK, A. Aplikace vystružovacich nástrojů s britty z cermetu a PVD povlakem. Brno 2011. Bakalárská práce. Vysoké učení technické v Brně, Fakulta strojního inženýrství, Ústav strojírenské technologie. p. 72. Head: Ing. Karel Kouřil, Ph.D. 
[13] DUGIN, A., POPOV, A. Increasing the accuracy of the effect of processing materials and cutting tool wear on the ploughing force values. In: Manufacturing Technology, Vol. 13, No. 2, pp. 169 - 173. ISSN 1213-2489.

[14] VASILKO, K., MACUROVÁ, A. Two local extremes of cutting speed. In: Manufacturing Technology, Vol. 12, No. 12, pp. $86-89$. ISSN 1213-2489.

[15] MANKOVA, I., VRABEL, M. BEŇO, J., KOVAC, P., GOSTIMIROVIC, M. Application of Taguchi Method and Surface Response Methodology to Evaluate of Mathematical Models to Chip Deformation when Drilling With Coated and Uncoated Twist Drills. In: Manufacturing Technology, Vol. 13, No. 4, pp. 492 - 499. ISSN 12132489.

\section{Paper number: M201435}

Copyright (C) 2014. Published by Manufacturing Technology. All rights reserved. 